\title{
Investigation of the Prevalence of Brucella Diagnosis in Serum and Milk in Cattle
}

U. Ülker

10.18805/IJAR.B-1404

\begin{abstract}
Background: Brucellosis is an infectious disease that affects both cattle and humans. Because brucellosis causes economic losses, serovalance studies are important in terms of eradication. Its diagnosis is integral to the design and implementation of preventive and management strategies for both cattle and humans. Various serological tests are commonly used in diagnostic processes.

Methods: This study was carried out in cattle farms located in Ankara, Çankırı, Kırşehir, Kayseri, Çorum, Yozgat, Kırıkkale, Nevşehir provinces in the Central Anatolia region of Turkey between January-2018 and December-2020. Bovines included in the study, simple random sampling method and 320 bovine blood serum and milk samples that were reported not to have Brucella vaccine were used. RBPT, SAT, CFT, I-ELISA tests were performed in the blood serum samples included in the study and I-Elisa, MRT tests were performed in the milk samples.

Result: The tests revealed that an average of $35.4 \%$ of the cattle had the bacteria while $64.5 \%$ of the raw milk samples were infected with brucellosis. The findings demonstrated the need to implement better strategies for managing and preventing brucellosis among animals, including vaccination. As a result, indirect ELISA (I-ELISA) method is considered as a useful, reliable, fast tool in the detection of Brucella from in milk and serum samples. However, it I-ELISA method can be used as a support for conventional tests in the initial isolation of waste materials and that its simultaneous use in field screening tests can be good diagnostic performance.
\end{abstract}

Key words: Brucellosis, Cattle, Milk, Serum, Seroprevelance.

\section{INTRODUCTION}

Brucellosis is an infectious and often subacute or chronic disease created by microorganisms belonging to the genus Brucella. Brucella bacteria are 0.6-1.5 $\mu \mathrm{m}$ in size, small, gramnegative, non-spore forming, aerobic or microaerophilic coccobacillus. It consists of 6 species: $B$. melitensis, $B$. abortus, B. suis, B. canis, B. ovis and B. neotomae. All species are catalase positive, but their oxidase and urease activities and $\mathrm{H}_{2} \mathrm{~S}$ formation are variable. The ideal growth temperature of Brucella bacteria is $37^{\circ} \mathrm{C}$, but they can also grow at $20-40^{\circ} \mathrm{C}$. They are sensitive to heat and disinfectants but resistant to penicillin (Alton, Forsyth, 1996). In domestic animals with economic value such as sheep, goats, cattle and pigs, settle in the genital organs such as testicles, breasts, uterus and infertility, resulting in large-scale economic losses. The disease is also known as fluctuating fever, Mediterranean fever and Maltese fever. It is also of great importance in terms of public health because of the contamination of infected animals with milk and dairy products, meat and meat products. One of the public health issues affecting the dairy cattle industry is the prevalence of brucellosis among the cows used to harvest milk especially in low-income regions and developing nations (Facciolà et al., 2018; Arenas-Gamboa et al., 2021).

Brucella is a disease that causes offspring to be discarded in domestic animals such as cattle, sheep, goats and pigs and is also transmitted from animals to humans, economically damaging and important from a public health point of view.
Veterinary Control Center Research Institute Directorate, Ankara, Turkey.

Corresponding Author: U. Ülker, Veterinary Control Center Research Institute Directorate, Ankara, Turkey.

Email: ufukmulker@yahoo.com

How to cite this article: Ülker, U. (2021). Investigation of the Prevalence of Brucella Diagnosis in Serum and Milk in Cattle. Indian Journal of Animal Research. DOI: 10.18805/IJAR.B-1404.

Submitted: 23-06-2021 Accepted: 23-09-2021 Online: 01-01-2022

In animals, this disease leads to serious losses both from the point of view of the breeder and the country's economy, such as offspring throwing, reduced milk yield, loss of breeding value, infertility (Khan and Zahoor, 2018). Controlling the condition still remains a challenge in many regions especially where effective vaccines are absent (Deka et al., 2018). Bosilkovski (2019) notes how humans contract the condition after consuming animal fluids or food products. As such, detecting the Brucella bacteria in animal fluids can be an effective strategy for preventing its incidence among humans. Since $B$. abortus is the predominant agent, most diagnostic tests focus on its detection (Acharya et al., 2016). In the prevention and control strategy of brucellosis, vaccination practices, control of animal movements and migrations, compliance with hygiene rules and culling of infected animals, including applications for diagnostic studies with screening tests in animals in the first place (Alton and Forsyth, 1996). Therefore, applications for performing 
diagnostic studies with screening tests are of critical importance.

In the present study, various tests for $B$. abortus on the blood and milk samples obtained from cattle in central Anatolia region of Turkey were performed to ascertain the prevalence of the condition in the country.

\section{MATERIALS AND METHODS}

Before starting the current study, ethics committee approval was obtained from the Ethics Committee of the Etlik Veterinary Control Research Institute Directorate (Decision date and number: 01.01.2018/4). The research was carried out in line with ethical principles and rules, protecting animal welfare and rights. This study was carried out in cattle farms located in Ankara, Çankırı, Kırşehir, Kayseri, Çorum, Yozgat, Kırıkkale, Nevşehir provinces in the Central Anatolia region of Turkey between January-2018 and December-2020. Bovines included in the study, simple random sampling method and 320 bovine blood serum and milk samples that were reported not to have Brucella vaccine were used. RBPT, SAT, CFT, I-ELISA tests were performed in the blood serum samples included in the study and I-Elisa, MRT tests were performed in the milk samples (Fig 1).

Rose Bengal Plate Test (RBPT): Pendik Veterinary Procured from the Control Institute (PVKE), RBPT was performed using RBPT antigen Brucella Serum Agglutination Test (SAT): Tube agglutination test antigen prepared with B. abortus S99 strain obtained from PVKE was used. Brucella agglutination degree in serum was evaluated as IU per milliliter. 30 per milliliter and Serum containing more IU was considered positive. Complement Fixation Test (CFT): from PVCE was performed with the provided CFT antigen. 20 of the serums Those who reacted with titers of IKFTU/ml or higher were considered positive (Anonymous, 2009). Milk ring test (MRT), In the study, 320 serum samples were tested using MRT. I-ELISA is a type of the test that can be used to detect the presence of antibodies against certain bacteriaes in bovine blood serum or milk samples (Laborde, et al., 2017). In the study, I-ELISA was conducted on both blood serum and milk samples since milk ELISA is internationally approved for lactating cows as an alternative to serum ELISA (Kumar et al., 2018). In total, ELISA tests were performed on 320 serum and milk samples.

\section{RESULTS AND DISCUSSION}

It details the findings of serological tests on serum and milk samples taken from cattle that were not vaccinated against Brucella in various provinces in the Central Anatolia region of Turkey (Table 1). Table 1 shows the results of each of the tests performed RBPT, SAT, CFT, I-ELISA in serum samples and I-ELISA, MRT in milk samples, as well as serum numbers from each region.

Table 2 then depicts the results of the serological tests performed to examine the proportion of animals that proved positive and negative for $B$. abortus from their blood and milk samples. From Table 1, the various tests performed on the serum of the bovine samples revealed different results. From the RBPT test, 118 of the 320 serum samples were found to be positive, representing $36.8 \%$ of the samples. In contrast, from the SAT, only $22.1 \%$ of the tested samples (71 out of 320). The SAT results were close to those obtained from the CFT test which also revealed that 61 out of 320 serum samples $(19.0 \%)$ were positive for brucellosis. The MRT presented a different result with $56.5 \%$ of the samples being positive. However, the ELISA serum test had the highest proportion of samples testing positive among the tests conducted. From the test $49.2 \%$ representing 156 of the 320 serum samples, were found positive for the antibodies.

The test results revealed that there was a high prevalence rate of brucellosis among non-vaccinated cattle in central Anatolia region of Turkey. Taking all the tests into consideration, the average value of the positive and negative results were as computed in Table 2 . The average values portray that at least $35.4 \%$ of all the cattle in the regions

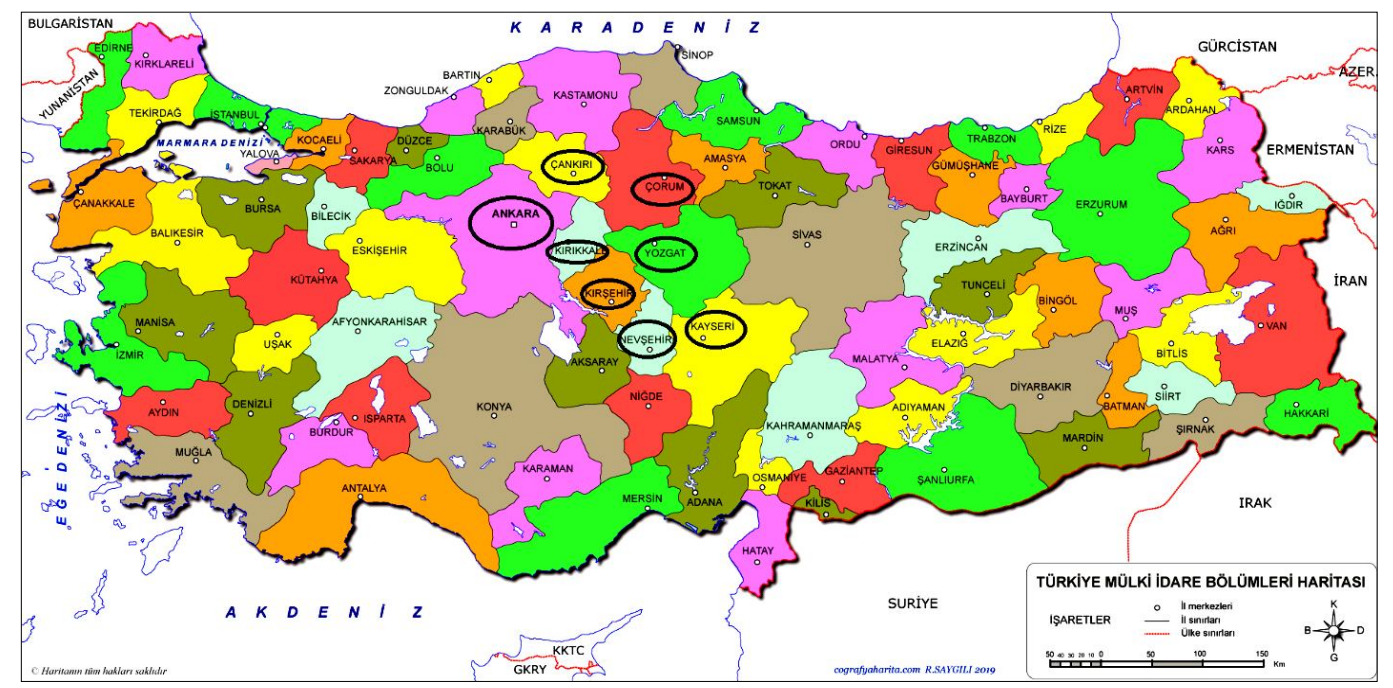

Fig 1: Locations where blood and serum samples are supplied. 


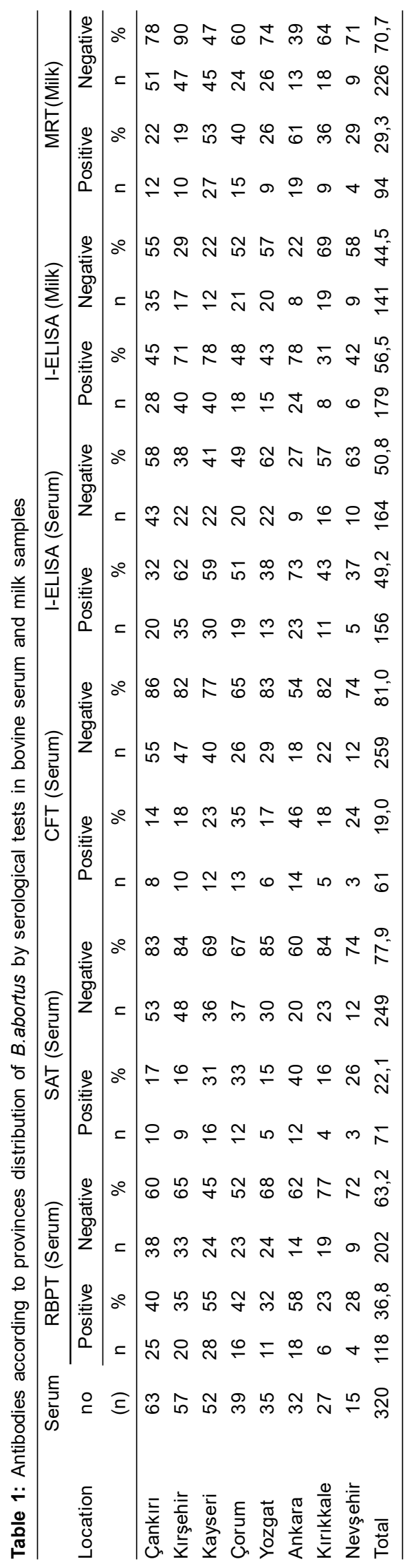

where the samples were taken from are positive for the $B$. abortus bacteria, with only $64.5 \%$ of them testing negative. ELISA presents the most complete test even when other tests produce negative results (Molavi et al. 2014). The prevalence rate for the disease was highest in the cities of Ankara, Kırşehir and Kayseri which all recorded 73\%, 62\% and $59 \%$ positive results in serum ELISA tests. The proportion of samples that tested positive was lowest in the cities of Kırıkkale and Çankırı for which the serum ELISA test revealed that $43 \%$ and $32 \%$ of the cattle were positive for the $B$. abortus bacteria.

Brucellosis is caused by bacteria of the brucella genus; It is a zoonosis that can be transmitted to humans through meat of animals such as sheep, goats, cattle, buffalo and pigs, body fluids such as milk and urine, dairy products prepared with infected milk, pregnancy materials of infected animals (Young, 2000). Brucellosis is an important zoonotic public health problem that affects societies socially and economically. The seroprevalence of brucellosis in the world and in our country varies according to geographical situation, level of development and socioeconomic status. The Central Anatolian region, which is located in Ankara, the capital city of Turkey, is a region that is located on the route of animal movements and has a strategic importance in terms of population density, geopolitics and control of animal movements. The definitive diagnosis of brucellosis is made by obtaining the microorganism from blood, bone marrow and other tissues. Serological diagnosis gains importance in cases where the microorganism cannot be obtained for various reasons (Young, 2000). The diagnosis of brucellosis is still commonly made by serology (Gotuzzo et al., 1992). Different rates are reported in studies to determine the prevalence of brucellosis. In the literature review, rates ranging from $1.8 \%$ to $25 \%$ are reported in our country (Abbasoğlu et al., 1990; Kalkan et al., 1999).

Within the scope of Brucella Eradication Project between 2000-2011 by the Ministry of Food, Agriculture and Livestock, General Directorate of Protection and Control, 5496 positive cases (8.2\%) were reported in 66475 animals in 2011. In 2011, it was reported that herd prevalence was $7.8 \%$ in cattle and $22.5 \%$ in sheep (Yazıcıoğlu, 2014). Esendal et al. (2000) suspected of brucellosis $47.2 \%$ by RBPT, \% by SAT in 250 bovine serum 51.6 ; \% by RBPT in 250 sheep-goat serum. They found a positive reaction of $37.6 \%, 44.4 \%$ with SAT. In our current study, RBPT $36.8 \%$, SAT $7122.1 \%$, CFT $19.0 \%$, I-ELISA $49.2 \%$ were determined in line with the results of 320 bovine blood serum samples. According to Babaoglu et al. (2018), it was determined that $17.32 \%$ of the milk samples of both vaccinated and unvaccinated cows were Brucellosis positivity. In our current study, MRT was $29.3 \%$ and I-ELISA was $56.5 \%$, in line with the results of 320 bovine milk samples. The positivity rate in MRT was $29.3 \%$, 36.8\% less than RBPT, but SAT was less than $22.1 \%$. While the positive rates in SAT and CFT were $22.1 \%$ and $19 \%$, similar results were found, RBPT was found to be high with $36.8 \%$. The high rate of positivity in the results 
Investigation of the Prevalence of Brucella Diagnosis in Serum and Milk in Cattle

Table 2: Average percentage results of B.abortus test results in milk and serum samples.

\begin{tabular}{|c|c|c|c|c|c|c|c|}
\hline \multirow[b]{3}{*}{ Brucella abortus } & \multicolumn{4}{|c|}{ Tests } & & & \multirow{3}{*}{ Average } \\
\hline & \multicolumn{3}{|c|}{ Serum } & & \multicolumn{2}{|c|}{ Milk } & \\
\hline & RBPT & SAT & CFT & I-ELISA & MRT & I-ELISA & \\
\hline Positive & $118(36.8 \%)$ & $71(22.1 \%)$ & $61(19.0 \%)$ & $156(49.2 \%)$ & $94(29.3 \%)$ & $179(56.5 \%)$ & $113(35.4 \%)$ \\
\hline Negative & $202(63.2 \%)$ & $249(77,9 \%)$ & $259(81.0 \%)$ & $164(50.8 \%)$ & $226(70.7 \%)$ & $141(44.5 \%)$ & $207(64.5 \%)$ \\
\hline Total & 320 & 320 & 320 & 320 & 320 & 320 & 320 \\
\hline
\end{tabular}

of RBPT may be due to the low positivity. The fact that CFT results are decisive as average positivity results is due to the fact that this test is accepted as the Gold standard test. In the Brucella screening tests, positivity rates were found to be higher with the I ELISA method compared to the sera analyzed by conventional methods. This may be related to the fact that I-ELISA detects lower and less Brucella antibodies and concludes. It is thought that the specificity and sensitivity of I-ELISA is higher than conventional tests. Despite the limitations of our current study, when the results obtained are examined, we think that the reason for the difference is the sample location, size, number of animals, the geopolitical situation in terms of animal mobility and the differences in the tests used in brucella disease.

\section{CONCLUSION}

The tests revealed that an average of $35.4 \%$ of the cattle had the bacteria while $64.5 \%$ of the raw milk samples were infected with the brucellosis. In conclusion, in order for Brucellosis prevention and eradication programs to be successful, animals should be regularly controlled and vaccinated and studies on the source of the disease should be expanded. In particular, we think that surveillance studies should be intensified and predominantly multicenter studies should be conducted.

\section{REFERENCES}

Abbasoğlu, U., Mevsim, G., Günay, G. (1990). Brucella antibody screening in a rural district of Ankara. Journal of Turkish Microbiology Society. 20: 189-192.

Acharya, K.P. Niroula, N. and Kaphle, K. (2016). Review of brucellosis in Nepal. Epidemiological Health. 38: e2016042. DOI: $10.4178 /$ epih.e2017018.

Alton G.G., Forsyth, J.R.L. (1996). Medical Microbiology. In: Medical Microbiology. [Samuel Baron, (editor)]. $4^{\text {th }}$ ed. Galveston (TX): University of Texas Medical Branch at Galveston.

Anonymous, (2009). Bovine Brucellosis. Eripim:http://www.oie.int/ fileadmin/Home/fr/Health_standards/tahm/2.04.03_ Bovıne_Brucell.pdf. (Access Date: 03.05.2014).

Arenas-Gamboa, A. M., Simmons, H.L., Krecek, R.C., Logan, L.L., Ellis, D., Ptaschinski, M. et al. (2021). AgSecure Africa ProgrammeTM: A Blended Training Approach for Africa. Journal of Veterinary Medical Education. e20200047.

Babaoglu, U., Ogutucu, H., Demir, G., Sanli, D., Babaoglu, A., and Oymak, S. (2018). Prevalence of Brucella in raw milk: An example from Turkey. Nigerian Journal of Clinical Practice. 21: 907-911. DOI:10.4103/njcp.njcp_211_17.
Bosilkovski, M. (2019). Brucellosis: Treatment and Prevention. In Baron, E.L. (Ed.), Retrieved December 8, 2020, from https://www.uptodate.com/contents/brucellosis-treatment -and-prevention.

Deka, R.P., Magnusson, U., Grace, D. and Lindahl, J. (2018). Bovine brucellosis: Prevalence, risk factors, economic cost and control options with particular reference to IndiaA review. Infection Ecology and Epidemiology. 8(1): 1-8. DOI:10.1080/20008686.2018.1556548.

Esendal, Ö.M., Yardımcı, H., Yıldırım, M., Altay, G (2000). The Use of Conventional Tests and Coombs Test in the Serological Diagnosis of Cattle, Sheep and Goat Brucellosis. IV. National Veterinary Microbiology Congress Book, Ankara p: 36.

Facciolà, A., Palamara, M., D'Andrea, G., Marano, F., Magliarditi, D., Puglisi, G., Visalli, G. (2018). Brucellosis is a public health problem in southern Italy: Burden and epidemiological trend of human and animal disease. Journal of Infection and Public Health. 11: 861-866. DOI: 10.1016/j.jiph.2018. 07.007.

Gotuzzo, E., Celillo, E. (1992). Brucella. In: Infectious Diseases. [Gorbach, S.I., Bartlett, J.G., Blacklow, N.R., (eds)]. Harcourt Brace Jovanovich Inc Philadelphla. pp: 1513-1518.

Khan, M.Z. and Zahoor, M. (2018). An overview of brucellosis in cattle and humans and its serological and molecular diagnosis in control strategies. Tropical Medicine and Infectious Diseases. 3: 65-79. DOI: 10.3390/tropicalmed 3020065.

Kalkan, A., Felek, S., Akbulut, A., Papila, Ç., Demirdağ, K., Kılıç, S.S. (1999). Determination of brucellosis seroprevalence in various risk groups in Elazig region. Journal of Infection. 13: $227-230$.

Kumar, V.N., Bharathi, M.V. and Porteen, K. (2018). Evaluation of milk ring test and milk ELISA in diagnosis of bovine brucellosis. The Indian Veterinary Journal. 95: 78-79.

Laborde, J., Sguazza, G., Fuentealba, N., Corva, S., Carbone, C., Galosi, C. (2017). Indirect ELISA (iELISA) for routine detection of antibodies against Minute Virus of Mice (MVM) in mice colonies. Revista Argentina de Microbiologia. 49: 210-215. DOI:10.1016/j.ram.2017.02.005.

Molavi, M., Sajjadi, H., Nejatizade, A. (2014). Effective methods for appropriate diagnosis of brucellosis in humans and animals (Review article). Online Journal of Animal and Feed Research. 4: 60-66.

Yazıcıoğlu, N. (2012). Brusella Eradikasyon Programı. IV. Türkiye Zoonotik Hastalıklar Sempozyumu (Gıda Kaynaklı Zoonozlar), Sempozyum kitabı, 99-106.

Young, E.J. (2000). Brucella Species, In: Principles and Practice of Infectious Diseases. [(Eds.) Mandell, G.L., Bennett, J., Dolin, R.]. $5^{\text {th }}$ ed., New York, Chuchill Livingstone pp: 2386-2391. 